NBER WORKING PAPER SERIES

INFLATION, TAX RULES, AND THE STOCK MARKET

\author{
Martin Feldstein
}

Working Paper No. 403

NATIONAL BUREAU OF ECONOMIC RESEARCH 1050 Massachusetts Avenue

Cambridge MA 02138

November 1979 
Inflation, Tax Rules and the stock Market

ABSTRACT

This paper shows how the interaction of tax rules and expected inflation can decrease substantially the share price per dollar of pretax earnings. The current analysis extends my earlier study (NBER Working Paper No. 276) by recognizing corporate debt, retained earnings, and the role of diverse shareholder investments. As before, the analysis separates household and institutional investors.

Martin Feldstein

National Bureau of Economic Research 1050 Massachusetts Avenue Cambridge, MA 02138

$617 / 868-3905$ 


\section{Inflation, Tax Rules, and the Stock Market}

\section{Martin Feldstein*}

The substantial fall in the real level of share prices during. the past decade has raised the cost of capital to firms and reduced their incentive to invest in new plant and equipment. 1 In a previous paper (Feldstein, 1978a), I explained how existing tax rules make the share prices of nonfinancial corporations sensitive to changes in the expected rate of inflation. An increase in the expected rate of inflation lowers the level of share prices immediately while continued inflation at any expected rate causes share prices to rise continually to maintain their real value.

A significant feature of that paper was the explicit recognition of two classes of portfolio investors: "households" that pay an income tax on dividends and interest and a capital gains

*Harvard University and the National Bureau of Economic Research. This paper is part of the NBER Study of Capital Formation and will be presented at the Rochester University Research Conference on October 25 and 26, 1979. I am grateful for discussions with Alan Auerbach, David Bradford, Jerry Green, Mervyn King, Lawrence Summers and other participants in the NBER summer institutes on Business Taxation and Finance. The views expressed in this paper are my own and not those of the NBER or Harvard University.

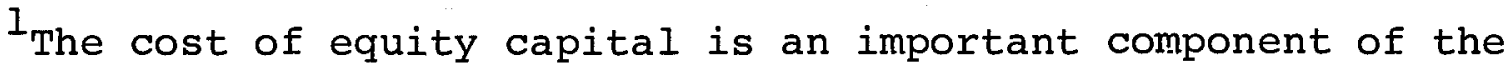
overall cost of capital if firms consider the repurchase of shares as an alternative to investment in new capacity (Tobin and Brainard, 1977) or if the firms' debt-equity ratios influence the cost of additional funds (Feldstein, Green and Sheshinski, 1979). 
tax on nominal capital gains, and "institutions" (pension funds, nonprofit organizations, etc.) that pay no tax on portfolio income or capital gains. Both types of investors hold equity shares despite the difference between them in the relative aftertax yields on stocks and bonds because of their desire to limit risk through portfolio diversification. ${ }^{I}$ In the simplified framework of the earlier paper, a rise in the expected rate of inflation unambiguously depresses the price per share that institutional investors are willing to pay but may raise the demand price that household investors are willing to pay. The change in the equilibrium share price that follows an increase in expected inflation depends on the portfolio adjustment behavior of these two types of investors.

Although the earlier analysis conveys the basic idea of how inflation affects share prices, it must be extended to provide a more realistic picture of the interaction of inflation and share prices. The present paper introduces three important aspects to the model of equilibrium share price behavior. First, the new analysis recognizes that firms borrow and that the existence of debt causes inflation to raise the firms' real after-tax earnings available for equity owners. Second, in contrast to the

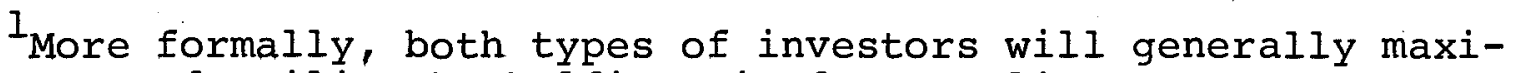
mize expected utility by holding mixed portfolios even though, in the absence of risk aversion, the difference in the relative after-tax expected yields on stocks and bonds would cause one type of investor to hold only one type of asset. See also Feldstein and Slemrod (1978) and Feldstein and Green (1979). 
assumption in the previous paper that firms distribute all earnings as dividends, the present analysis assumes a realistic ratio of retained earnings to dividends. The effect of this is to magnify the impact on share prices of changes in inflation or other variables. Finally, the present analysis recognizes that households invest in a much wider range of assets than stocks and bonds including real estate, consumer durables, noncorporate businesses, depletable natural resources, and such "store-ofvalue" assets as land, gold and antiques; some of these investment opportunities actually become more attractive when the rate of inflation increases. I Households may also respond to lower prospective yields on stocks and bonds by increasing consumption. The households' broad range of alternatives to investment in equities implies in general that their opportunity cost of holding shares does not vary in the same way as that of institutions and, in particular, that it does not vary only with the real net yield on bonds. This broader set of alternatives is recognized in the current analysis by explicitly relaxing (but not completely eliminating) the previous link between the real net yield on bonds and the required yield on equities. With these extensions, the current analysis identifies six ways in which the interaction of inflation and tax rules affects share prices: (I) Historic cost accounting for depreciation and

$I_{\text {The interaction of inflation and tax rules affect the net }}$ yield on these assets very differently from the way they effect either stocks or bonds; see Feldstein (1978b) on land and gold and Hendershott (1979) on housing. 
existing methods of inventory accounting raise corporate taxes. (2) The deduction of nominal interest payments lowers corporate taxes. 1 (3) The net increase in corporate tax payments reduces dividends and retained earnings, thus lowering tax payments by shareholders. (4) The nominal increase in the value of the corporation's capital stock induces a capital gains tax liability for shareholders. (5) Because households pay tax on nominal interest income, inflation lowers the real net yield on bonds as an alternative to share ownership. ${ }^{2}$ (6) The favorable tax rules for investment in land, gold, owner-occupied housing, etc. imply that the real net opportunity cost of shareholding does not fall as much as the real net yield on bonds and may actually rise. In considering these interactions of inflation and tax rules, it is important to distinguish households and non-taxable institutions and to recognize that share prices represent an equilibrium for these two groups. All of these ideas are developed more fully in the present paper.

Although it is analytically useful to calculate how inflation affects share prices on the assumption that the pretax return

In evaluating the impact of inflation on the total taxes paid on the capital income of the nonfinancial corporations, it is important to bear in mind that this reduced corporate tax liability is almost exactly offset by the increased tax liability of the creditors who must pay tax on nominal interest receipts (see Feldstein and Summers, 1979).

${ }^{2}$ As I emphasized in Feldstein (1978a), this stands in sharp contrast to the popular notion that share prices are depressed because of high nominal interest rates. 
per unit of capital is unchanged, a fall in the share price per dollar of corporate capital would in fact reduce the equilibrium size of the corporate capital stock and thereby raise the pretax return until the share price per dollar of capital returned to its initial equilibrium. ${ }^{1}$ The current paper presents some illustrative calculations of the magnitude of the fall in the equilibrium capital stock that would result under certain simplifying assumptions.

In the first section of this paper, I analyze an economy in which shares are owned only by tax exempt institutions. The more complex effects of inflation on households' demand for equity shares are examined in section 2. The third section examines the market equilibrium with both types of investors.

The limitations of the analytic structure should be stressed at the outset. The model presented here does not represent a full general equilibrium picture of the effects of inflation on share prices. Some of the values that are treated as fixed parameters should be regarded as endogenous variables in a larger system. The role and complete consequences of macroeconomic policy and debt policy remains vague. The pretax yield on capital in the noncorporate sector is not explicitly treated as an endogenous variable, The dynamic specification ignores transitional

$I_{\text {Under certain conditions, the equilibrium share price per }}$ dollar of capital is unity but the presence of taxation may cause a different value; see Auerbach (1978), Bradford (1979), Feldstein and Green (1979) and King (1977). 
issues and focuses on steady state values. I believe that the model is nevertheless rich enough and realistic enough to demonstrate the principal chanels through which the interaction of inflation and tax rules affects share prices.

The present paper is not, however, an attempt to explain the total fall in the real value of share prices. The behavior of share prices during the past decade and a half may reflect not only the interaction of taxes and inflation but also the cyclical downturn in economic activity and pretax profitability, the inability of investors to evaluate real corporate earnings in an inflationary environment, investors' perception of an increased risk in equity investment, etc. ${ }^{1}$ The goal of the present paper is more modest: to examine the way in which tax rules and inflation interact in affecting the share prices of nonfinancial corporations and to show that the net effect of inflation is likely to be negative. This conclusion stands in sharp contrast to papers in which Fama (1979), Hendershott (1979) and Modigliani and Cohn (1979) have argued that the interaction of taxes and inflation has raised share prices above the even lower levels to which they would otherwise have fallen.

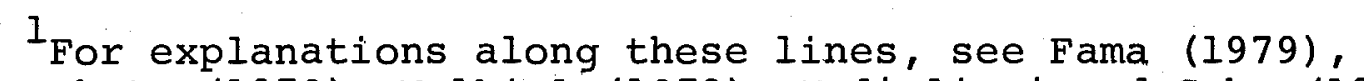
Hendershott (1979), Malkiel (1978), Modigliani and Cohn (1979), and summers (forthcoming). 


\section{Institutional Investors}

This first section analyzes an economy in which equity shares are owned only by tax exempt institutions like pension funds and nonprofit organizations. ${ }^{I}$ This provides a simple way of separating the effect of inflation on corporate taxes from its effects on the taxes paid by households and shows why it is important to distinguish the two classes of investors in the complete analysis. The analysis here shows that an increase in the expected rate of inflation unambiguously decreases the attractiveness of equity shares relative to bonds for this important group of investors and would therefore lower the share value per unit of capital.

Consider first an economy in which there is no inflation. Each share of stock represents the ownership claim to a single unit of capital (i.e., one dollar's worth of capital valued at its reproduction cost) and to the net earnings that it produces. The marginal product of capital (net of depreciation), f', is subject to a corporate income tax at effective rate $\tau_{I} ;$ in the absence of inflation, this effective rate of tax is less than the statutory rate $(\tau)$ because of the combined effect of the investment tax credit and accelerated depreciation. The corporation

$I_{\text {These institutions own a significant and growing fraction }}$ of corporate stock, especially of the stock of major publicly traded corporations. Probably because of their exemption from capital gains taxes, these institutions account for a disproportionately large share of all transactions in equity shares. 
borrows b dollars per unit of capital and pays interest at rate r. Since these interest payments are deducted in calculating corporate income that is taxed at the statutory rate $\tau$, the net cost of these borrowed funds is $(1-\tau)$ br. The net return to equity investors per unit of capital is therefore $\left(1-\tau_{1}\right) f^{i}-(1-\tau)$ br. To avoid the extra notation of two different corporate tax rates, I shall define the "equivalent pretax return" $\rho$ to satisfy $(1-\tau) \rho$ $=\left(1-\rho_{1}\right) f^{\prime} ;$ i.e., $\rho$ is the pretax rate of return which, if taxed at the statutory rate, would yield the same after-tax return as occurs when the actual pretax return is taxed at the lower "no inflation" effective tax rate. The net return to equity investors per unit of capital in the absence of inflation is thus $(1-\tau)(\rho-b r)$. What happens to this net return when the inflation rate rises? For simplicity, the analysis considers an instantaneous and unanticipated increase to $\pi$ which is expected to persist forever. Under existing U.S. tax law, inflation raises taxable profits (for any fixed level of real profits) in two ways. First, the value of depreciation allowances is based on the original or "historic" cost of the asset rather than on its current value. When prices rise, this historic cost method of depreciation causes the real value of depreciation to fall and the real value of taxable profits to rise. ${ }^{1}$ second, the cost of maintaining

${ }^{2}$ Specific estimates of the magnitude of this effect are discussed below. For a more general discussion, see Feldstein, Green and Sheshinski (1978) and Feldstein (1979), Hong (1977), Motley (1969) and Van Horne and Glassmire (1971) discuss the implications of historic cost depreciation for share values in the context of a model with a single investor whose discount rate is unchanged by inflation. 
inventory levels is understated for firms that use the first-in/ first out (FIFO) method of inventory accounting. ${ }^{I}$ A Iinear approximation that each percentage point of inflation increases taxable profits per unit of capital by $\mu$ implies that the existing treatment of depreciation and inventories reduces net profits by $\tau \mu$ per unit of capital.

When there is a positive rate of inflation, the firms' net interest payments $((I-\tau) b r)$ overstate the true cost to the equity owners of the corporations' debt finance. Against this apparent interest cost it is necessary to offset the reduction in the real value of the corporations' net monetary liabilities. These net monetary liabilities per unit of capital are the difference between the interest-bearing debt (b) and the non-interest-bearing nominal assets (a) that consist primarily of cash and net accounts receivable.

Combining the basic net profits per unit of capital, the extra tax caused by the existing depreciation and inventory rules, and the real gain on net monetary liabilities yields the real net return per unit of capital:

$$
z=(1-\tau)(\rho-b r)-\tau \mu \pi+(b-a) \pi
$$

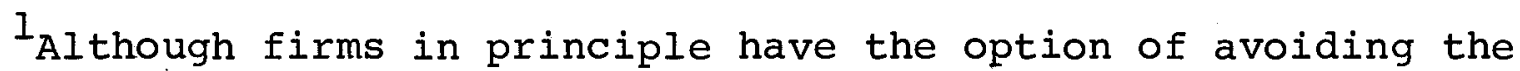
extra tax by using the last-in/first-out (LIFO) method of inventory accounting, a total of $\$ 7$ billion in extra taxes were paid in 1977 because firms apparently regarded that as less costly in a larger sense than switching from FIFO to LIFO. 
If $q$ is the share value per unit of equity (i.e., per unit of capital net of its prorata share of debt), the corporate return per dollar of equity is $e=z / q(I-b) I^{I}$

If the corporation paid all of its earnings out to shareholders in the form of dividends, e would also be the net return to the institutions that own those shares. In fact, corporations distribute a fraction $d$ as dividends and retain the rest. ${ }^{2}$ Since a dollar of retained earnings is worth $p$, each dollar of corporate earnings net of the corporate income tax is worth $d+(1-d) p$ dollars. ${ }^{3}$ The real net return to institutional investors per dollar of equity shares is thus

$$
e_{n i}=\frac{z\left[d+(1-d)_{q}\right]}{q(1-b)}
$$

where the subscript $\mathrm{n}$ indicates that this is a net return and the subscript $i$ indicates that this is the net return for institutional investors.

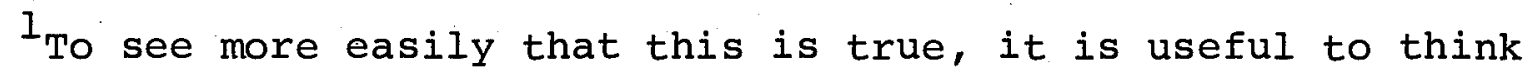
about the corresponding aggregates. Let $\mathrm{K}$ be total capital and $\mathrm{B}=\mathrm{bK}$ be the corresponding aggregate debt. The value of the equity shares are $q(\mathrm{~K}-\mathrm{B})$ and the total equity earnings are $\mathrm{zK}$. The corporate equity yield is thus $\mathrm{zK} / \mathrm{q}(\mathrm{K}-\mathrm{B})=\mathrm{z} / \mathrm{q}(\mathrm{l}-\mathrm{b})$.

2 I assume that $d$ (like b) does not change with the rate of inflation. Although this is done primarily to focus attention on the more direct effects of inflation, neither ratio has changed significantly during the past 15 years.

${ }^{3}$ If $\mathrm{p}$ is less than 1 , institutional investors would obviously prefer to have all income distributed. Because of their different tax situation, households will generally prefer some retained earnings even if $p$ is less than 1 , The distribution fraction observed in the economy reflects the firms' balancing of these conflicting interests. For an explicit model of the determination of dividend policy, see Feldstein and Green (1979). 
A simple model of share valuation implies that the price that the investor would be willing to pay per share would make the real net earnings per dollar of equity equal to the real net return on bonds, $r-\pi$. More realistically, investors require a higher yield on equity investments than they do on the apparently less risky bonds. If the risk differential required by institutional investors is denoted ${ }^{I} \delta_{\text {is }}$, their portfolio equilibrium condition can be written

$$
e_{n i}=r-\pi+\delta_{i s}
$$

Using equation 1.2 to substitute for $e_{n i}$ in equation 1.3 gives a portfolio equilibrium condition that can be solved explicitly for the share price:

$$
q=\frac{d z}{(I-b)\left(r-\pi+\delta_{i s}\right)-z(1-d)}
$$

The effect of inflation on the equilibrium share price depends on the change in the real rate of interest $(r-\pi)$ and the change in the equity earnings net of corporate income $\operatorname{tax}(z)$. Econometric studies indicate that the nominal interest rate rises point-for-point with sustained changes in the rate of inflation,

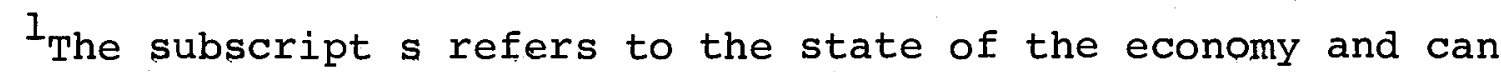
temporarily be ignored. In general, $\delta_{\text {is }}$ will be an increasing function of the number of shares that the investor holds in equilibrium. The current assumption that all shares are held by institutional investors implies that $\delta$ is does not depend on the rate of inflation if we ignore any effect of changes in the constant inflation rate on the perceived riskiness of stocks. 
$\mathrm{dr} / \mathrm{d} \pi=1.1$ It is important to emphasize that this "Fisherian" feature of the economy is an empirical regularity and not a theoretical necessity. As Feldstein, Green and Sheshinski (1978) emphasize, the response of the nominal interest rate to inflation in an economy without government bonds depends on tax rates, depreciation rules and investor behavior. ${ }^{2}$ The actual behavior of the interest rate depends also on government debt policy ${ }^{3}$ and on the supply of debt by noncorporate borrowers. The remainder of the paper assumes that $d r / d \pi=1$, i.e., that the real interest rate remains constant.

With a constant real rate of interest, equation 1.5 shows that inflation lowers the equilibrium share price if $\mathrm{dz} / \mathrm{d} \pi<0$

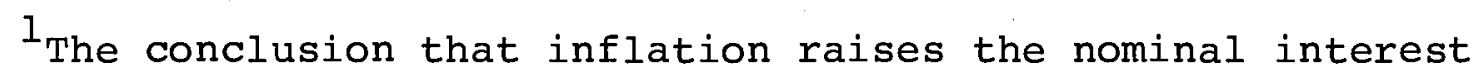
rate while leaving the real rate unchanged has been supported by a large number of studies. See Fisher (1930), Yohe and Karnovsky (1969), Feldstein and Eckstein (1970) and, more recently, Fama (1975) and Feldstein and Summers (1978).

${ }^{2}$ Calculations by Feldstein and summers (1978) show that, with existing tax rules, the interest rate would rise by slightly more than the rise in the rate of inflation if the difference in the real net yields on stocks and bonds for a typical individual investor is to be maintained. They found empirically that the interest rate movement did not maintain this real net yield difference but satisfied $\mathrm{dr} / \mathrm{d} \pi=1$.

${ }^{3}$ Feldstein (1978c) presents an explicit model of equilibrium growth that shows how different government debt policies can modify the real rate of interest in a way that is independent of the rate of inflation, 
and raises the equilibrium share price if $\mathrm{dz} / \mathrm{d} \pi>0$. From equation 1.1

$$
\begin{aligned}
\frac{d z}{d \pi} & =-(1-\tau) b-\tau \mu+b-a \\
& =\tau(b-\mu)-a .
\end{aligned}
$$

Recent values of these parameters imply that $d z / d \pi$ is negative and therefore that inflation would reduce the short-run equilibrium share price in an economy in which only tax exempt institutions own shares. In 1977, nonfinancial corporations had a total capital stock of $\$ 1,684$ billion and owed net interestbearing liabilities of $\$ 595$ billion, ${ }^{l}$ implying that $b=0.353$. The net non-interest-bearing assets (consisting of cash and net trade credits) have a value of $\$ 133.9$ billion, implying that a $=0.079$. Since the corporate tax rate in 1977 was $\tau=0.48$, these figures imply that $\mathrm{dz} / \mathrm{d} \pi=0.090-\tau \mu$.

While it is difficult to calculate $\mu$ as precisely as $\tau, b$ and $z$, it is clear that $\tau \mu$ exceeds 0.09 and therefore that $d z / d \pi<0$. Recall that $\mu \pi$ is the overstatement of taxable profits per dollar of capital caused by inflation at rate $\pi$. Feldstein and Summers (1979) estimate that in 1977 inflation caused an overstatement of taxable profits of $\$ 54.3$ billion of which $\$ 39.7$ billion was due to low depreciation and $\$ 14.6$ was due to artificial inventory

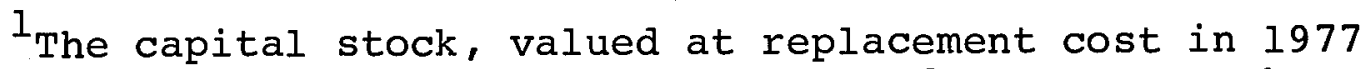
dollars, is estimated by the Department of Commerce. The net liabilities are based on information in the Flow of Funds tables. See Feldstein and Summers (1979) for more details on both numbers. 
profits. Thus in $1977 \mu \pi=54.3 / 1684=0.032$. The implied value of $\mu$ depends on the rate of inflation that was responsible for these additional taxable profits. For the inventory component of the overstated profits, the relevant inflation rate is the one for the concurrent year; for the depreciation component, the relevant inflation rate is a weighted average of the inflation rates since the oldest remaining capital was acquired but with greater weight given to inflation in more recent years. The consumer price index rose 6.8 percent in 1977, an average of 7.2 percent in the preceeding five years, and 4.5 percent and 1.9 percent in the two previous five year periods. ${ }^{I}$ An inflation rate of 7.0 percent is therefore a reasonable upper bound for the relevant rate and 5.0 percent is a reasonable lower bound. A value of $\pi=0.06$ implies that $\mu=0.53$ and therefore that $\tau \mu=0.256$; even at the upper bound of $\pi=0.07, \mu=0.46$ and $\tau \mu=0.22$. Both of these values are clearly above the critical value of 0.09 required for $\mathrm{dz} / \mathrm{d} \pi>0$. In the analysis that follows, I shall assume $\mu=0.53$, a value that is also implied by an alternative calculation presented in the appendix to this paper. ${ }^{2}$

Two more parameter values are required to calculate explicitly the effect of inflation on the real rate of return to equity

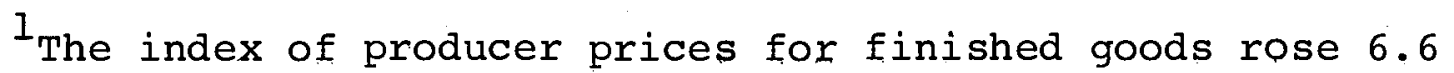
percent in 1977 and an average of 5.9 percent for the previous decade, essentially the same as the CPI,

2 The alternative calculation is based on selecting a hypothetical investment and seeing how inflation changes the after-tax internal rate of return with existing tax laws. 
capital: the equivalent pretax rate of return $(\rho)$ and the real interest rate $(r-\pi)$. For the period from 1948 through 1976, the cyclically-adjusted rate of return on capital in the nonfinancial sector averaged 11.2 percent (Feldstein and Summers, 1977); using this value implies $\mathrm{f}^{\prime}=0.112$. In the absence of inflation, the tax rules as of 1977 imply an effective corporate tax rate of $\tau_{I}=0.38 .^{I}$ Since $\rho$ is defined by $(I-\tau) \rho=\left(I-\tau_{I}\right) \mathrm{f}^{\prime}, \rho=0.134$. The real interest rate is estimated most easily for a period with low and quite stable inflation. Between 1960 and 1964, the annual rates of increase of the consumer price index varied between 1.0 percent and 1.6 percent with a mean of 1.24 percent. The interest rate on Baa bonds varied between an annual average of 5.19 percent in 1960 and 4.83 percent in 1964 with an overall average of 5.00 percent. These figures imply a real interest rate of 3.75 percent for Baa bonds. ${ }^{2}$

$I_{\text {This }}$ figure is derived in the following way. The total 1977 tax on nonfinancial corporations $(T)$ is equal to the tax on real capital income ( $\left.\tau, f^{\prime} K\right)$ plus the excess tax caused by inflation $(\tau \mu \pi \mathrm{K})$ minus the Eax reduction associated with the deduction of interest expenses ( $\tau \mathrm{rbK}$ ). According to the national income accounts, the 1977 tax liability of nonfinancial corporations was $\$ 59.0$ bilition, the net interest payments were $\mathrm{rbK}=\$ 33.7 \mathrm{billion}$, and profits (with the capital consumption and inventory valuation adjustments) were $\mathrm{f} \cdot \mathrm{K}-\mathrm{rbK}=\$ 113.9$ billion. Combining these with the Feldstein and Summers (1979) estimate of the excess tax due to inflation $(\tau \mu \pi \mathrm{K}=\$ 19.1$ billion) and the statutory tax rate of $\tau=0.48$ implies that the effective corporate rate in the absence of inflation would be $\tau_{1}=0.38$.

${ }^{2}$ Since the Baa rate fell monotonically during the early 1960 's, the implied real interest rate might be as low as 3.5 percent. (The Baa rate of 8.97 percent in 1977 implies an anticipated inflation rate of approximately 6.25 percent. Since then the rise in interest rates implies an increase in anticipated inflation to between 7.50 and 7.75 percent. These calculations of course assume the continuous maintenance of a constant real rate of interest.) 
Combining these parameter estimates implies that the real rate of return to equity per dollar of capital in the absence of inflation would be (from equation 1.1):

$$
\begin{aligned}
z & =(1-\tau)(\rho-b r) \\
& =.52(.134-.353(.0375)) \\
& =.0628
\end{aligned}
$$

With a six percent rate of inflation, $z$ falls to:

$$
\begin{aligned}
z= & (1-\tau)(\rho-b r)-\tau \mu \pi+(b-n) \pi \\
= & .52(.134-.353(.0975))-.48(.53)(.06) \\
& \quad+(.353-.079) .06 \\
= & .0530
\end{aligned}
$$

The rate of return at the level of the corporation thus falls by approximately one percentage point or one-sixth of its pre-inflation value.

The share price equation (1.5) contains two parameters that have not yet been evaluated: the dividend pay-out rate (d) and the risk differential ( $\left.\delta_{\text {is }}\right)$. In 1977, the corporations paid dividends equal to 45.3 percent of their real after tax profits; this payout ratio has varied cyclically but averaged 45.4 percent during the preceeding 15 year period. I shall assume $d=0.45$ in all of the calculations. The risk differential $\left(\delta_{\text {is }}\right)$ can be calculated directly from the share price equation 1.4 by imposing the long-run equilibrium condition that $q=1$. Thus 1.4 implies 
(1.8)

$$
\begin{aligned}
\delta_{i s} & =\frac{z}{I-b}-(r-\pi) \\
& =\frac{.0628}{.647}-.0375 \\
& =.0596
\end{aligned}
$$

Thus stocks yield 9.71 percent in this no-inflation equilibrium or 5.96 percent more than the yield on bonds.

It is now possible to calculate the effect of inflation on the short-run equilibrium share price for this economy in which all shares are owned by institutional investors. For a six percent inflation, equation 1.5 implies that

$$
\begin{aligned}
q & =\frac{z d}{(I-b)\left(r-\pi+\delta_{i s}\right)-z(I-d)} \\
& =\frac{.45(.0530)}{(.647)(.0375+.0596)-.0530(.55)} \\
& =.708
\end{aligned}
$$

The short-run equilibrium share price falls to 71 percent of its no-inflation value. Note that the proportional fall in $\mathrm{q}$ is nearly twice as great as the proportional fall in $z$, a magnification that results from recognizing the effect of retained earnings.

In considering this fall in the short-run equilibrium share price, it is important to bear in mind that it treats the risk differential $\left(\delta_{\text {is }}\right)$ as fixed. Although inflation may in fact alter the perceived riskiness of investments in stocks and bonds, this is ignored here in order to focus on the interaction of 
inflation and tax rules. ${ }^{1}$

It is also important to emphasize that the new share price in equation 1.10 is calculated on the assumption that the pretax rate of return $(\rho)$ remains unchanged and therefore that the capital stock of the corporate sector is unchanged. The lower share price would reduce investment in the corporate sector and this would cause the pretax rate of return $\rho$ to rise. The reduced rate of investment would continue until the share price returned to its original long-run equilibrium value of $q=1$. Ignoring this eventual return to $q=1$ causes equation 1.9 to overstate the actual short-run fall in the share price.

To specify the capital adjustment process correctly requires at least a two-sector model of the economy in which capital and labor can both move from the nonfinancial corporate sector (and from other activities where inflation raises the effective tax rate) to activities like owner-occupied housing that are not taxed more heavily when the inflation rate rises. Consider instead a simpler calculation of the required reduction in the corporate capital stock if relative prices remain unchanged and the reduction in capital is the only way in which the pretax rate

$l_{\text {The risk differential would also change with the rate of }}$ inflation because of the induced shift in share ownership. Discussion of this will be postponed until the demand for shares by household investors has been considered. 
of return is increased, ${ }^{1}$ With this simplification, it is easy to calculate the long-run reduction in the capital stock that is induced by a six percent inflation. It follows from the share price equation ( 1.4 or 1.9 ) that returning to the original share value of $q=1$ is equivalent to raising $z$ to the value that prevailed in the absence of inflation or, from equation 1.6 , $z=0.0628$.

Equation 1.1 can be used to calculate the value $\rho *$ that is required to make $\mathrm{z}=0.0628$ with $\pi=0.06$ :

$$
\begin{aligned}
.0628= & (1-\tau)\left(\rho^{*}-b r\right)-\tau \mu \pi+(b-a) \pi \\
= & .52\left(\rho^{*}-.353(.0975)\right)-.48(.53)(.06) \\
& \quad+(.353-.079)(.06) \\
= & .52 \rho^{*}+.0191
\end{aligned}
$$

or $\rho^{*}=.1575$. Thus the value of $\rho$ must rise from 0.134 to 0.1575 to reestablish the long-run equilibrium. The corresponding change in the capital stock depends on the form and parameters of the production function. A Cobb-Douglas technology with a capital elasticity of 0.2 implies an 18 percent reduction in the equilibria capital stock.

In summary, in an economy with our existing tax rules but in which all shares were owned by institutions that paid no "personal"

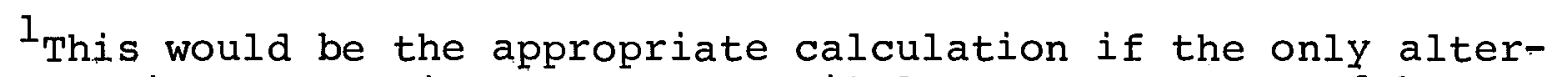
native to investment in corporate capital were government debt. More generally, it is necessary to recognize the changes in the relative product prices and in the allocation of labor among the sectors of the economy. 
tax on income or capital gains, a six percent inflation would induce a fall in the short-run equilibrium share price of nearly 30 percent and a fall in the long-run capital intensity of between 15 and 20 percent. The analysis for an economy with household as well as institutional investors is more complex and the results are more ambiguous. Before considering the behavior of this complete market equilibrium, it is useful to begin by analyzing the share valuation equation for households. 


\section{Household Investors}

Household investors differ from institutional investors in three significant ways. First, households pay an income tax on dividends and a capital gains tax on the appreciation of share values. A particularly important aspect of this is the taxation of the nominal appreciation that results from capital gains. Second, because households pay tax on nominal interest income, the real net yield on bonds varies inversely with the rate of inflation. Third; households invest in a wide range of assets, a characteristic that eliminates the close link between the yields on bonds and the required yield on stocks.

This section develops the portfolio equilibrium condition for household investors and then derives the households' demand for shares as a function of their price and yield. The next section then combines the demand functions of households and institutions to study how inflation changes the market equilibrium price and capital intensity.

The real return per unit of capital after corporate income taxes but before personal taxes is the same as it was for institutional investors:

$$
z=(1-\tau)(p-b r)-\tau \mu \pi+(b-a) \pi
$$

and the corporate return per dollar of equity is again $e=z / q(1-b)$. A fraction $d$ of this return is paid out as dividends and subject to individual income tax at rate $\mathrm{m}$. The fraction that is retained adds $(1-d) q$ to the value of the firm. This real increase in the 
firm's value is eventually subject to a capital gains tax when the stock is sold. The postponed tax liability can be expressed instead as an equivalent present-value tax rate $\mathbf{c}$ on accruing capital gains; since the actual liability is postponed and the gain taxed at less than the rate on ordinary income, $\mathbf{c}<\mathrm{m}$.

Inflation reduces these net earnings even further by imposing an additional tax on nominal capital gains. More specifically, even though the real share price remains constant at the new real equilibrium value $q$, inflation causes the nominal share price to rise at $100 \pi$ percent a year. The real value of this nominal gain at any time is thus $\pi q$ per share or $\pi q(1-b)$ per unit of capital. 1 This entails no real gain but does induce an ultimate capital gains tax liability with an equivalent accrual amount of crq(l-b) per unit of capital.

The real net return to household investors per dollar of equity value is thus:

$$
e_{n h}=\frac{z[d(1-m)+(1-d)(1-c) q]-c \pi q(1-b)}{(1-b) q}
$$

where the subscript $h$ indicates that this is a net yield to households.

For institutional investors, portfolio equilibrium was characterized by equating this net equity yield to the sum of the real

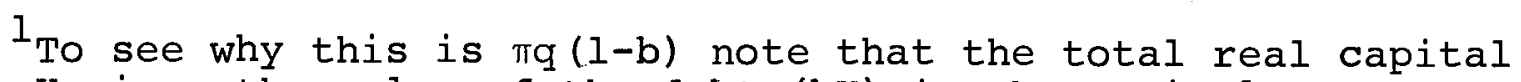
stock $K$ minus the value of the debt (bK) is the capital share of the equity owners and is valued at $m$ per unit of net capital. Thus the total equity value is $E=q(1-b) K$. In addition to any retained earnings, the nominal value of equity rises at the rate $\pi \mathrm{E}=\pi q(1-b) \mathrm{K}$. The nominal gain per unit of capital is thus $\pi q(1-b)$. 
net yeild on bonds and a risk differential that would in general vary with the number of shares that those investors own. For household investors, I shall adopt a similar equilibrium condition that the required net equity yield may be written as the sum of two components: a real net yield on alternative assets $\left(n_{s}\right)$ and a risk differential that depends on the number of shares that households own: ${ }^{1}$

$$
e_{n h}=n_{s}+\delta_{h s}
$$

The subscript $s$ on $\mathrm{n}_{\mathrm{s}}$ indicates that the real net yield on alternative assets varies with the state of the economy, i.e.; with the rate of inflation.

For ordinary bonds, the real net yield is $(1-m) r-\pi ;$ the assumption that $\mathrm{dr} / \mathrm{d} \pi=1$ implies that the real net yield on such bonds falls by the fraction $m$ of any increase in the inflation rate. Investments in other assets are treated much more favorably in an inflationary economy. Owner-occupied housing is not affected by depreciation rules, the nominal capital gains are largely untaxed, and the deductibility of nominal mortgage interest payments reduces the real net cost of mortgage finance. Investments in nondepreciable property (land, timber, depletable resources,

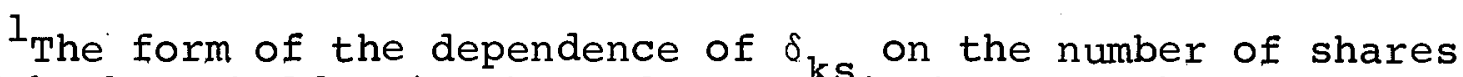
owned by households will be made explicit below. The value of $\delta$ wili also depend on the risk per share, This additive separabillity assumption is obviously a simplification that would only be consistent with expected utility maximization on very stringent assumptions. 
gold, etc.) are also not affected by the historic cost depreciation rules. Although these investments entail eventual capital gains tax liabilities on their nominal appreciation, this relatively small tax is often more than offset by the tax deductibility of interest payments on the debt associated with these investments. Although investments in depreciable real estate are disadvantaged by the historic cost depreciation rule, the relatively high ratio of debt to total capital for such investments implies that even the reduction in real depreciation is often more than offset by the deductibility of nominal interest. ${ }^{1}$ on balance, therefore, inflation may lower, raise or leave unchanged the yield on alternative investments to which household investors compare the yield on equity. ${ }^{2}$ The risk premium that a household requires to hold an additional share of equity should be an increasing function of the amount of risk that the household is already bearing. This relation (and the similar one for institutional investors) will be discussed explicitly in section 3 . Combining equations 2.2 and 2.3 gives an explicit equation for the price per share that household investors would be willing to pay:

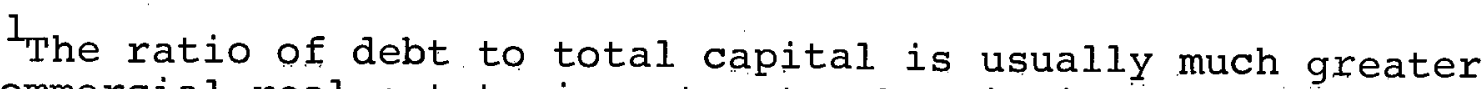
for commercial real estate investments than it is for nonfinancial corporations in general.

2 The change in $\mathrm{n}_{\mathrm{s}}$ will differ among households according to their individual income tax brackets. Moreover, the new equilibrium will also involve some capitalization of yield differentials. Because of differences in tax rates among households, this capitalization cannot be complete for all households. 
$(2.5)$

$$
q=\frac{(1-m) z d}{(1-b)\left(n_{s}+\delta_{h s}\right)+(1-b) c \pi-(1-d)(1-c) z} .
$$

The analysis in section 1 showed that the net effect of higher inflation on depreciation, inventories and the deductibility of corporate interest expenses reduces the corporation's net of tax income, z. Equation 2.5 shows that this lower value of $\mathrm{z}$ reduces the share price. The taxation of the households' nominal capital gains, reflected in the term (1-b)c $\pi$ in the denominator of equation 2.5, further depresses the share price. Thus if the household's required yield on equities $\left(n_{s}+\delta_{h s}\right)$ uses or remains unchanged, the interaction of inflation and tax rules unambiguously reduces the share price that households are willing to pay. Since section 1 showed that the institution's demand price would unambiguously decline, a constant or higher value of $\mathrm{n}_{\mathrm{s}}+\delta_{\mathrm{hs}}$ means that a higher rate of inflation would unambiguously reduce the equilibrium share price.

A significant fall in the household's required yield on equities is required to prevent a decline in their demand price for shares. Even if such a decline in $n_{s}+\delta_{h s}$ does prevent a decline in the household's demand price, the unambiguous reduction in institutions' demand for shares might cause a fall in the market equilibrium price of shares.

The magnitude of the decline in $\mathrm{n}_{\mathrm{s}}+\delta_{\mathrm{hs}}$ that would maintain the household's demand for equities is easily calculated with the help of equation 2.5. It is necessary first to evaluate the two tax rates paid by household investors, $m$ and $c$. For the average 
tax rate on dividends (m), I shall use the weighted average of shareholder marginal tax rates, weighting by the amount of dividends received; Feldstein and Summers (1979) report the value $m=0.39 .^{1}$ It is more difficult to estimate the relevant rate of capital gains tax, c. Long-term capital gains are taxed at about half of the rate on dividends ${ }^{2}$ when the gain is realized. However, since gains are taxed only when they are realized, the effective rate is reduced by the postponement of realization. In addition, capital gains that have accrued on assets that are passed on at the death of their owner completely avoid tax on the previously accrued gain because the new owner is permitted to "step up" his basis to the value at the time of receipt for the purpose of calculating future capital gains liabilities. A conservatively low value of $\mathbf{c}=0.05$ will be used.

With these values of $\mathrm{m}$ and $\mathrm{c}$ and the other parameter values that were obtained in section 1 , it is now possible to use equation 2.5 to derive the value of $n_{s}+\delta_{h s}$ that is consistent with

$l_{A}$ one percent increase in the dividend receipts of each taxpayer would increase the income tax liability by 39 percent of the additional dividends. This calculation is done with the NBER TAXSIM model based on 1976 tax rates.

2 Until 1978, half of long-term gains were excludable in calculating taxable income; since then, the exclusion has increased to 60 percent. The total tax rate on capital gains also depends on the availability of the alternative tax method (until 1978), the treatment of the excluded portion of gains as a tax preference, and the reduction in the amount of earned income eligible for the maximim tax provision (until 1978), 
zero inflation and an initial share price of $\mathrm{q}_{0}=1$. More specifically, with $z_{o}=0.0628, d=0.45$ and $b=0.353$, equation 2.5 implies that $\mathrm{n}_{\mathrm{s}}+\delta_{\mathrm{hs}}=0.0774$.

A rise in the inflation rate rises to $\pi=0.06$ would reduce $\mathrm{z}_{\text {from }} \mathrm{z}_{0}=0.0628$ to $z_{1}=0.0530$ and would add $(1-b) \mathbf{c} \pi=0.00194$ to the denominator to reflect the taxation of nominal capital gains. If the required rate of return on equities remains unchanged at $\mathrm{n}_{\mathrm{s}}+\delta_{\mathrm{hs}}=.0774$, the demand price implied by equation 2.5 drops from $\mathrm{q}_{0}=1$ to $\mathrm{q}_{1}=0.598$, a more substantial reduction than the decline in the institutional investors' demand price to 0.708 .

To prevent this decline in the household's demand price, the required rate of return would have to drop from 0.0774 to 0.0623 or less. 2 Only if such a decline in $\mathrm{n}_{\mathrm{s}}+\delta_{\mathrm{hs}}$ occurred could the households' demand for equities increase. The possibility of such a decline and the corresponding change in the equilibrium share price when households and institutions are considered together is one of the cases considered in the next section.

\footnotetext{
${ }^{1}$ See page 16 for the calculation that $\pi=0.06$ implies $z_{1}=0.0570$.

2 The value of 0.0623 is obtained from equation 2.5 by setting $\mathrm{q}=1, \mathbf{z}=.0530$ and $(1-\mathrm{b}) \mathrm{c} \pi=0.00194$ and then solving for $\mathrm{n}_{\mathrm{s}}+\delta_{\mathrm{hs}}$
} 


\section{Market Equilibrium}

The separate analyses of institutional and household investors have shown how inflation affects these two components of the total demand for shares. An increase in the rate of inflation unambiguously reduces the institutional investors' demand because the real net yield on equities falls while the corresponding yield on the alternative investment in bonds does not. For household investors, the demand for equities declines unless the real net yield on the portfolio of alternative financial and real investments falls enough to offset the lower return on equities and the extra tax on nominal capital gains. If the equity demands of both households and institutions decline, the market price of shares must also decline in the short-run and the capital stock of the nonfinancial corporate sector must decline in the long-run.

More generally, a higher rate of inflation might reduce the real net yield on the alternative assets in which households invest by enough to increase their demand for equity shares. The change in the market equilibrium price then depends on the way in which the risk differentials of institutions and households ( $\delta$ is and $\delta_{h s^{\prime}}$ ' respond to changes in the distribution of share ownership, The present section therefore begins by presenting an explicit model of the determination of $\delta_{\text {is }}$ and $\delta_{\mathrm{hs}}$

The risk premium that an institution requires to hold an additional share of equity should be an increasing function of the amount of risk that the household is already bearing, More explicitly, I shall assume that $\delta_{\text {is }}$ is proportional to the 
standard deviation of the return on the equity portion of the existing portfolio. ${ }^{1}$ The source of this uncertainty is the variability of the pretax return on capital $\rho i^{2}$ the variance of $\rho$ will be written $\sigma_{\rho}^{2}$. Equations 1.1 and 1.2 imply that the variance per dollar of equity investment is $[d+(1-d) q]^{2}(1-\tau)^{2} \sigma_{\rho}^{2} /(1-b)^{2} q^{2}$. If institutions own $\mathrm{s}_{\text {is }}$ shares when the economy is in state $\mathrm{s}$, the dollar value of their equity investment is $s_{i s} q_{s}$ where $q_{s}$ is the price prevailing in state $s$. The standard deviation of the return on the equity portion of the institutions' portfolio is the product of the dollar value of the equity investment: $s_{\text {is }}\left[d+(1-d) q_{S}\right]$ $(1-\tau) \sigma_{\rho}(1-b)$. If the risk differential between the yields on bonds and stocks is proportional to this standard deviation, $\delta_{\text {is }}$ can be written:

$$
\delta_{i s}=\delta_{i} s_{i s}\left[d+(1-d) q_{s}\right](1-\tau)(1-b)^{-1} \sigma_{\rho}
$$

where $\delta_{i}$ is a risk-aversion constant for institutions.

Note that all of the variables that determine $\delta_{\text {is }}$ are measurable except $\delta_{i}$ and $\sigma_{\rho}$ and that only their product matters. Recall that equation 1.8 showed that in general $\delta_{\text {is }}=\mathbf{z} /(1-b)-(r-\pi)$ and that with no inflation $\delta_{\text {is }}=0.0596$. In 1967, before the

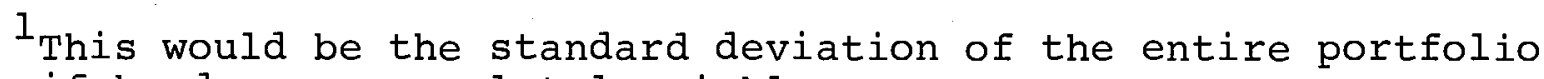
return if bonds were completely riskless.

2 The current analysis ignores any direct effect of increased inflation on perceived risk in order to focus analytic attention on the interaction of taxes and the steady-state rate of inflation. 
inflation rate began to accelerate, institutions held approximately $\$ 100$ billion of corporate equities. ${ }^{1}$ I shall take the share price in 1967 to be $q_{0}=1$. Measuring the total equity value in billions of dollars implies $S_{i o}=100$. Equation 3.1 then indicates that $\delta_{i} \sigma_{\rho}=0.741 \cdot 10^{-3}$.

The risk sensitivity parameter for households $\left(\delta_{h} \sigma_{\rho}\right)$ can be obtained in essentially the same way. The assumption that the risk premium that a household requires to hold additional shares of equity is proportional to the standard deviation of the return on the equity portion of the existing portfolio ${ }^{2}$ implies that

(3.2) $\delta_{h s}=\delta_{h} s_{h s}\left[d(1-m)+(1-d)(1-c) q_{s}\right](1-\tau)(1-b)^{-1} \sigma_{\rho}$ where $\delta_{h}$ is the risk aversion constant for households. The analysis in section 2 showed that, in the absence of inflation, an equilibrium share price of $\mathrm{q}_{\mathrm{O}}=1$ implies $\mathrm{n}_{\mathrm{O}}+\delta_{\text {ho }}=0.0774$. For any value of $\mathrm{n}_{\mathrm{o}}, \delta_{\text {ho }}$ is calculable and equation 3.2 can be used to derive $\delta_{\mathrm{h}^{\sigma}}{ }_{\mathrm{s}}$. This specification implies that $\mathrm{n}_{0}$ is the minimum yield on equities that is required to induce households to own any equities at all; it is equal to the real net yield to households on the

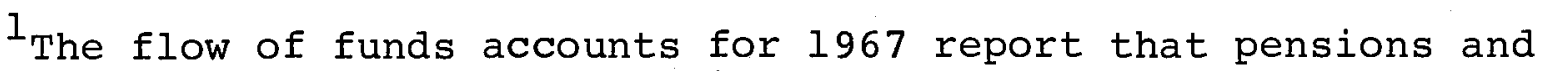
insurance companies owned $\$ 79$ billion of corporate equities at market value. Of the $\$ 720$ billion of equities owned by "households, personal trusts and nonprofit organizations," approximately $\$ 20$ billion are attributable to nonprofit organizations.

2 This would be most appropriate if the other assets in the households' portfolio could be treated as riskless but, in any case, the simple additive separability and proportionality specification of the required equity yield must be regarded as a useful approximation rather than a general result. 
portfolio of alternative assets (in the absence of inflation) plus the required risk differential when the households currently own no equities. For example, $\mathrm{n}_{\mathrm{o}}=0.04$ implies $\delta_{\mathrm{ho}}=0.0374$ and $\delta_{h} \sigma_{\rho}=0.834 \cdot 10^{-4} \cdot 1$ More generally $\delta_{h} \sigma_{\rho}=\left(0.173-2.230 \mathrm{n}_{0}\right) 10^{-3}$; thus with $\mathrm{n}_{0}=0.05, \delta_{h_{0}}=0.615 \cdot 10^{-4}$ while with $\mathrm{n}_{0}=0.03$, $\delta_{h} \sigma_{\rho}=0.106 \cdot 10^{-3}$. The risk sensitivity parameter of households is thus approximately one-tenth of the corresponding parameter for institutions, a difference that primarily reflects the much larger total wealth of households.

The equilibrium share price and distribution of share ownership at any inflation rate must satisfy three conditions: the institutional portfolio balance condition, the household portfolio balance condition, and the requirement that the total demand for shares by households and institutions equals the existing supply. In the short run, with the stock of capital fixed, this provides three equations that simultaneously determine $q_{s}, s_{h s}$ and $s_{i s}$. In the long-run, the share price must equal one and the three equations determine the equilibrium size of the corporate capital stock and its distribution between households and institutions.

Consider first the short-run equilibrium with a fixed stock of capital and a fixed number of shares $\bar{s}$. The institutional portfolio balance condition can be written (from 1.4):

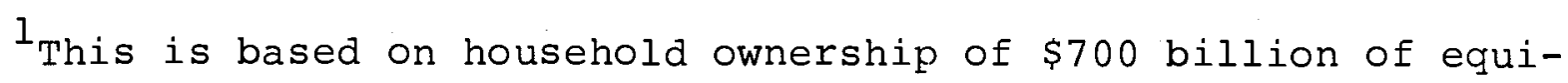
ties at market value in 1967. 
(3.3) $\quad q=\frac{z d}{(1-b)\left(x-\pi+\delta_{i s}\right)-z(1-d)}$

where

$$
\mathbf{z}=(1-\tau)(\rho-b r)-\tau \mu \pi+(b-a) \pi
$$

and

$$
\delta_{i s}=0.741\left(10^{-3}\right) s_{i s}\left[d+(1-d) q_{s}\right](1-\tau)(1-b)^{-1}
$$

Note that the dependence of $\delta_{\text {is }}$ on $S_{\text {is }}$ implies that 3.3 can be thought of as the institutions' inverse demand function for shares; ceterus paribus a higher price is associated lwith a smaller number of shares. The corresponding household portfolio balance condition is (from 2.5)

$$
q=\frac{(1-m) z d}{(1-b)\left(n_{s}+\delta_{h s}\right)+(1-b) c \pi-z(1-d)(1-c)}
$$

where

$$
\begin{array}{r}
\delta_{h s}=\left(0.173-2.230 n_{0}\right)\left(10^{-3}\right) s_{h s}\left[d(1-m)+(1-d)(1-c) q_{s}\right]_{1} \\
(1-\tau)(1-b)^{-1} .
\end{array}
$$

Finally, the demand for shares must equal the fixed supply:

$$
s_{i s}+s_{h s}=\bar{s}
$$

These six equations determine the equilibrium share price $q$, the share ownership of households and institutions ( $S_{i s}$ and $S_{h s}$ ) and the incidental parameters $\mathbf{z}, \delta_{\text {is }}$ and $\delta_{\mathrm{hs}}$. 
The numerical parameter values in equation 3.5 and 3.7 , were selected to make the equations consistent with the initial equilibrium of $\pi=0$ and $q=1$ with share ownership $s_{i o}=100$ and $s_{\text {ho }}=700$. The response of $q$ to changes in $\pi$ depends on the initial level of $\mathrm{n}_{\mathrm{o}}$ and on the way in which it is changed by inflation as well as on the other parameter values that have been discussed at earlier points in the paper. This is seen more clearly when equations 3.3 through 3.8 are reduced to a set of three equations evaluated at $\pi=0.06$. A subscript 1 will be used to distinguish the equilibrium values at $\pi=0.06$ from the equilibrium value with no inflation that are subscripted with a zero. For convenience, I will define $\hat{\mathrm{S}}_{\mathrm{il}}=10^{-3} \mathrm{~S}_{\mathrm{il}}$ and $\hat{\mathrm{S}}_{\mathrm{hi}}=10^{-3} \mathrm{~S}_{\mathrm{hl}}$. Equations $3.3,3.4$ and 3.5 can then be reduced to: 1

$$
.1601 \hat{\mathrm{S}}_{i 1} \mathrm{q}_{1}+.1957 \hat{\mathrm{S}}_{i 1} \mathrm{q}_{1}^{2}-.004888 \mathrm{q}_{1}-.02385=0 .
$$

Similarly, equations 3.5 and 3.7 can be reduced to

$$
\begin{aligned}
& \left(.0247-.3183 \mathrm{n}_{\mathrm{o}}\right) \hat{\mathrm{S}}_{\mathrm{hl}} \mathrm{q}_{1}+\left(.04700-.6059 \mathrm{n}_{\mathrm{o}}\right) \hat{\mathrm{S}}_{\mathrm{hl}} \mathrm{q}_{1}^{2} \\
& -\left(.02575-.647 n_{1}\right) q_{1}-0.01455=0
\end{aligned}
$$

Finally,

(3.11) $\quad \hat{\mathrm{S}}_{\mathrm{hl}}+\hat{\mathrm{S}}_{\mathrm{il}}=800$

$I_{\text {This }}$ uses the previous calculation that $z=0,053$ at $\pi=.06$. 
Consider first the implications of an initial alternative yield of $\mathrm{n}_{0}=0.04$ that does not change at all when the inflation rate rises to 6 percent $\left(n_{1}=0.04\right)$. Solving equations 3.9 through 3.11 indicates that the price falls from $\mathrm{q}_{0}=1$ to $\mathrm{q}_{1}=0.74$. Institutions increase their share ownership from $\mathrm{S}_{\text {is }}=100$ billion shares $\left(\right.$ at $\left.q_{0}=1\right)$ to $S_{i l}=122$ billion shares $\left(\right.$ at $\left.q_{1}=0.74\right)$; the fall in the price per share implies that the total value of their equity holdings fall from $\$ 100$ billion to $\$ 90$ billion. Households reduce their share ownership from $\mathrm{S}_{\mathrm{ho}}=700$ billion shares to $\mathrm{S}_{\mathrm{hl}}$ $=678$ billion shares and thus reduce the value of the equity holdings from $\$ 700$ billion to $\$ 502$ billion. The institutional ownership increases from 12.5 percent of total equities to 15.3 percent. 1

These results are not sensitive to changes in the initial level of the alternative yield. The assumption that $\mathrm{n}_{0}=0.03$ (instead of $\mathrm{n}_{0}=0.04$ ) and that this does not change when the inflation rate rises to 6 percent implies that inflation reduces the price to $\mathrm{p}_{1}=0.76$. Institutional holding rises to 118 billion shares and therefore to the same $\$ 90$ billion as with $\mathrm{n}_{0}=0.04$.

$1_{\text {Between }} 1967$ and 1977 , corporate equities declined from approximately 40 percent of household assets to approximately 25 percent. Equities remained at 55 percent of private pension assets and rose from 9 percent of the assets of state and local government employee retirement funds to 23 percent. Among insurance companies, equities remained at 11 percent of total assets. Thus institutions as a whole increased the fraction of their assets devoted to equities. Since the total assets of these institutions also rose some faster than the total assets of households, the fraction of equities held by households declined from about 88 percent to about 78 percent. 
The assumed change in the yield on alternative assets caused by inflation does however have a substantial impact. If $\mathrm{n}$ falls from $n_{0}=0.04$ to $n_{1}=0.03$, the equilibrium price only falls from $\mathrm{q}_{0}=1$ to $\mathrm{q}_{1}=0,89$. This fall in $\mathrm{n}_{1}$ implies that households would actually increase their shareholding to 704 billion shares while institutions reduced their shareholding. The fall in $\mathrm{n}_{1}$ required to keep the equilibrium share price unchanged implies an even more implausible decrease in shareholding by institutions; if $\mathrm{n}$ falls from $\mathrm{n}_{0}=0.04$ to $\mathrm{n}_{1}=0.024$, the equilibrium price remains unchanged at $\mathrm{q}=1$ but institutions reduce their shareholds from $\$ 100$ billion to $\$ 81$ billion. Finally, it is interesting to note that a fall in $\mathrm{n}_{1}$ from 0.04 to 0.027 would be enough to increase the price that households would be willing to pay in isolation ${ }^{2}$ but leads to a fall in the market equilibrium price $\left(q_{1}=0.94\right)$ and a substantial increase in the number of shares held by households (to 722 billion shares).

The equilibrium conditions of equations 3.3 through 3.8 can now be used to calculate the change in the pretax rate of return ${ }^{3}$ that is required for long-run equilibrium. Instead of regarding

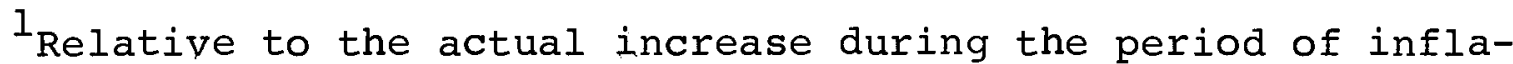
tion described in the previous footnote.

2 See above, page 27 , where it is noted that any fall greater than 0.015 would raise household demand for shares.

${ }^{3}$ And therefore, in a simplified model, in the capital stock. 
$\rho$ as exogenous (in equation 3.4 ) and $q$ as endogenous, the analysis will now set $q=1$ and solve for the value of $\rho$ that is consistent with $\pi=0.06$. The solution indicates that with $n_{0}=n_{1}=0.04$, $\rho$ rise from 0.134 to 0.157 . The 17 percent rise in the required marginal product of capital implies a significant fall in the capital stock of nonfinancial corporations. ${ }^{1}$ Consider again the simplifying assumptions of section 1 that relative prices remain unchanged and that the fall in the corporate sector capital stock is the only way to raise the pretax rate of return. A Cobb-Douglas technology with a capital elasticity of 0.2 implies that raising $\rho$ from 0.134 to 0.157 requires an 18 percent fall in the capital stock. If inflation lowers the yield on alternative assets so that $\mathrm{n}_{1}=0.03$, the required rate of return rises to $\rho=0.143$ and the Cobb-Douglas technology implies an 8 percent fall in the capital stock. Although the simplifying assumptions mean that these figures are only rough approximations, they do indicate the significant effect that the interaction of inflation and existing tax rules may have on the incentive to invest.

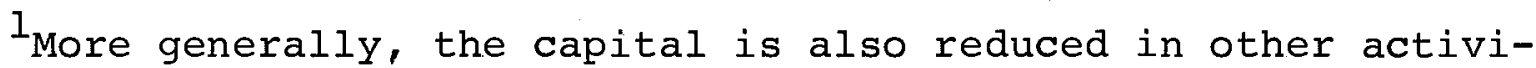
ties that are more heavily taxed because of inflation. 
4. Conclusion

The analysis in this paper has shown that, because of existing tax rules, a permanent increase in the expected rate of inflation will depress the price of equity shares and will reduce the size of the equilibrium capital stock in the affected industries. This conclusion is based on calculations that use likely values of the tax and financial variables and that explicitly recognize the important roles of debt finance and retained earnings.

A number of other recent studies that have reached the opposite conclusion (that the interaction of taxes and inflation does not depress share prices) are based on a faulty or incomplete description of the tax effects. For example, Fama (1979) concludes that taxes could not be responsible for the fall in real share values during the 1970's because the ratio of corporate taxes to gross corporate income (before subtracting depreciation and real interest payments) has fallen since the $1960^{\prime} \mathrm{s}$. I do not understand the purpose of this comparison since the denominator does not refer to equity income and the numerator does not include all of the taxes paid by equity investors. Modigliani and Cohn (1979) refer to the fact that inflation reduces the real value of depreciation but 
uncierestimate the magnitude of this effect by more than 60 percent. 1 They also ignore the extra tax on the portfolio investors and the way in which the interaction of inflation and taxes alters the real net yields available on alternative assets. Hendershott's (1979) extension and critique of Feldstein (1978) avoids many of the problems of other studies but his empirical results are difficult to interpret because he inadveitently uses the pre-jnflation nominal yield on debt to describe portfolio balence. None of the studies with which I am familiar recognize the importance of distinguishing anong investors in different tax situations, either generally or the particular distinction between households and tax-free institutions that has been emphasized in the current paper. There are of coursf: $a$ number of ways in which the present siudy could be extended and strengthened. Like any model of a single market, the results could be improved by imbedding the current model in a mors complete general equilibriurn system. In

$I_{\text {Modigliani and Cohn estimate the effect of jnflation on }}$ allowable depreciation by the capital consumption adjustment (CCA) estimated by the Department of Commerce. The CCA actually reflects two countervailirg differences between real stcaight-lire depreciation and the depreciation allowed for tax purposes: acceleration makes tax-deductible depreciation exceed straight-line depreciation while inflation reduces the value of tax-deductible depreciation. In 1977, for example, the "acceleration component" raised tax deductible depreciation by $\$ 25.0$ billion while the "inflation component" reduced tax depreciation by $\$ 39.7$ billion. The $\$ 14.7$ billion difference between these two is the net CCA figure of the type used by Modigliani and Cohn; it is only 37 percent of the true reduction in depreciation caused by inflation. (Although the "acceleration component" grew during the 1970's, this was almost entirely due to changes in tax laws in the 1960 's and to the growth of investment. The favorable tax rules and the likely future would therefore have been anticipated in the late $1960^{\prime} \mathrm{s}$ and reflected in share prices at that time. Only the subsequent unanticipated inflation and the associated loss of real depreciation would affect subsequent share price moments.) 
this way, the effect of reductions in the stock of nonfiancial corporate capital on the yields in other markets could be explicitly evaluated. An explicit model of the adjustment of the capital stock would permit a more accurate evaluation of the initial change in price. A better empirical specification of the yields on the alternative assets in the household's portfolio would also be desirable. Finally, a more general specification of the other factors that influence the movement of share prices is a necessary prerequisite to direct empirical measurement of the extent to which the poor performance of the stock market during the 1970's is due to the interaction of inflation and existing tax rules. ${ }^{1}$ 


\section{Appendix}

Historic Cost Depreciation and Effective Tax Rates

The text of this paper introduced the parameter $\mu$ to measure the extent to which inflation raises taxable corporate income by reducing the real value of depreciation allowances and inventory costs. Although the component of $\mu$ caused by existing inventory methods could be calculated directly, the more important depreciation component required the rather arbitrary selection of "the" inflation rate responsible for the 1977 understatement of real depreciation. The rate of $\pi=.06$ was selected to reflect experience during the life of the then existing capital stock. The implied value of the depreciation component of $\mu$ is 0.39 . Although the results are not very sensitive to plausible variations in their inflation rate, it seems desirable to estimate this parameter by an alternative method.

The current appendix uses the "hypothetical project" technique that I employed with Lawrence Summers in an earlier study (Feldstein and Summers, 1978). This method is completely free of the recent historic experience. It nevertheless produces a value of the depreciation parameter (say, $\mu_{1}$ ) that is extremely close to the estimate based on the national account data. The similarity of the two results provides substantial support for this value. Consider" a "standard investment" that in the absence of taxes 
has an internal rate of return of 12 percent. 1 Let the nominal rate of return that the firm can afford to pay for funds invested in this project. In the absence of tax this would be 12 percent; with pure debt finance and economic depreciation, the firm could pay this nominal return regardless of the corporate income tax. But less than economic depreciation would reduce this maximum potential rate of return. 2

The Feldstein-Summers study considered how a 6 percent inflation would change the maximum potential interest rate that a firm could pay on the standard project if the project was financed with one-third debt and two-thirds equity and if the real net equity yield to typical individual investors had to exceed their real net yield on debt by 6 percent. The analysis showed that a maximum potential nominal interest rate of 3.3 percent with no inflation would rise to 11.3 percent with a 6 percent inflation. 3 The assumption of one-third debt finance and a 6 percent yield differential implies that a 6 percent inflation rate would lower the total

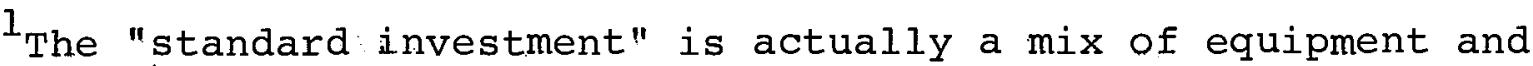
structures, each with its own exponential output decay structure. see Feldstein and Summers, 1978, page 67.

${ }^{2}$ For a more complete description, see Feldstein and summers (1978) pp. 57-73.

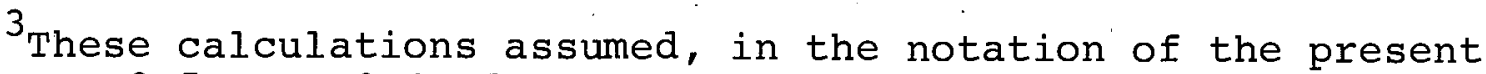
paper, $\tau=0.5, \mu=0.4, \mathrm{~d}=0.5$ and $\mathrm{c}=0.1$. 
maximum potential real yield on capital by 1.2 percentage points: ${ }^{1}$ $\tau \mu_{1} \pi=0.012$ or, with the value of $\tau=0.5$ used in that calculation, $\mu_{1}=0.40$. This estimate is almost identical to the value inferred from the national account data and embodied in the total value (including inventory effects as well) of $\mu=0.53$ that is used in the text.

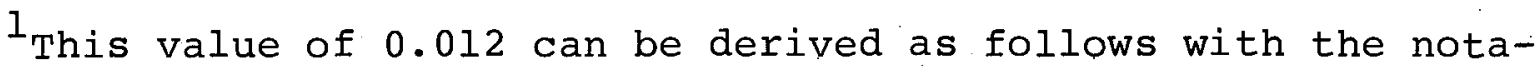
tion of the present paper. The assumption of a 6 percent yield differential implies $(1-m) i-\pi+.06=[d(1-m)+(1-d)(1-c)](z /(1-b))$ - c $\pi$. The earlier study found $i=0.033$ when $\pi=0$ and $i=0.113$ when $\pi=0.06$. These imply $z=.0709$ when $\pi=0$ and $z=.0656$ when $\pi=0.06$. In the present paper, $\tau \mu \pi$ is the change in $z$ induced by the effect of historic cost depreciation; using this would imply $\mu_{1}=0.363$. But the Feldstein-summers calculation assumes a rise in the real interest rate and therefore an understatement of $\mu_{1}$. The total nominal return that the firm pays for funds is $N=b(I-\tau) i$ $+z+(1-b) \pi$. In the absence of inflation, $N=0.0764$ while at $\pi=.06, N=0.1244$. The real return on capital falls from 0.0764 to 0.0694 , a fall of 0.012 . 


\section{$\underline{\text { References }}$}

Auerbach, Alan, "Share Valuation and Corporate Equity Policy, NBER Working Paper No. 255, 1978.

Bradford, David, "The Incidence and Allocation Effects of a Tax on Corporate Distributions," NBER Working Paper. No. 349, 1979.

Fama, Eugene, "Stock Returns, Real Activity, Inflation and Money," University of Chicago, 1979, mimeographed.

Fama, Eugene, "Short-Term Interest Rates as Predictors of Inflation," American Economic Review (June 1975), 269-82.

Feldstein, Martin, "Inflation and the Stock Market," American Economic Rèview, forthcoming. (1978a).

-------, "The Effect of Inflation on the Prices of Land and Gold," NBER Working Paper No. 296 (1978b).

------, "Fiscal Policies, Inflation and Capital Formation, American Economic Review, forthcoming (1978c).

------, "Adjusting Depreciation in an Inflationary Economy:

Indexing versus Accelerated Depreciation," NBER Paper No. 395 (1979).

-

Interest Rate," Review of Economics and Statistics vol. 52

(November 1970), 363-75.

Feldstein, Martin and Jerry Green, "Why Do Companies Pay Dividends?" NBER Working Paper, 1979.

------- and Eytan Sheshinski, "Inflation and Taxes in a Growing Economy with Debt and Equity Finance, Journal of Political Economy, Vo. 86, No. 2, S53-S70, 1978 . 
-- - - "--, "Corporate Financial Policy and Taxation in a Growing Economy, Quarterly Journal of Economics, forthcoming. Feldstein, Martin and Joel Slemrod, "Personal Taxation, Portfolio Choice and the Effect of the Corporation Income Tax," NBER Working Paper No. 24I, 1978. Feldstein, Martin and Lawrence Summers, "Is the Rate of Profit Falling?" Brookings Papers on Economic Activity, 1:1977, 211-227.

-- "-- " Inflation, Tax Rules and the Long-Term Interest Rate," Brookings Panel on Economic Activity $1: 1978,61-99$. - "Effects of Inflation on the Taxation of Capital Income in the Corporate sector," NBER Working Paper No. 312, 1979.

Fisher, Irving, The Theory of Interest (MacMillan), 1930. Hendershott, Patric, "The Decline in Aggregate Share Values: Inflation and Taxation of the Returns From Equities and Owner-Occupied Housing," NBER Working Paper No. $370,1979$. ------ and Sheng Cheng $\mathrm{Hu}$, "Inflation and the Benefits from Owner-Occupied Housing," NBER Working Paper No. 383, 1979. Hong, Hai, "Inflation and the Market Value of the Firm: Theory and Tests," The Journal of Finance, Vol. XXXII, No. 4 (September 1977).

King, Mervyn, Public Policy and the Corporation, London: Chapman and Hall, 1977.

Malkiel, Burton

Modigliani, Franco and Richard Cohn, "Inflation, Rational Valuation and the Market," Financial. Analysts Journal (March/April 1979). 
Motley, Brian, "Inflation and Common Stock Values: Comment," Journal of Finance. (June 1969).

Summers, Lawrence, "Inflation, Taxation and Share Valuation," forthcoming, 1979 .

Tobin, James and W.C. Brainard, "Asset Markets and the Cost of Capital," in B. Belassa et al (eds.), Economic Progress, Private Values and Public Policy, 1977.

Van Horne, James and William Glassmire, Jr., "The Impact of Unanticipated Changes in Inflation on the Value of Common Stocks," Journal of Finance, 1971.

Yohe; William P. and Denis Karnowsky, "Interest Rates and Price Level Changes, 1952-69," Federal Reserve Bank St. Louis Rev. 51 (December 1969). 